\title{
The Effect of Targeted Grazing and Biological Control on Yellow Starthistle (Centaurea solstitialis) in Canyon Grasslands of Idaho
}

\author{
John M. Wallace, ${ }^{1}$ Linda M. Wilson, ${ }^{2}$ and Karen L. Launchbaugh ${ }^{3}$
}

Authors are ${ }^{1}$ Research Support Scientist and ${ }^{2}$ Research Scientist, Department of Plant, Soil, and Entomological Sciences, University of Idaho, Moscow, ID 83844-2339, USA; and ${ }^{3}$ Associate Professor, Department of Rangeland Ecology and Management, University of Idaho, Moscow, ID 83844-1135, USA.

\begin{abstract}
Yellow starthistle (Centaurea solstitialis L.) is an invasive weed of significant importance on rangelands in the western United States. Field experiments were conducted in 2003 and 2004 to determine the effect of targeted grazing on yellow starthistle growth and bud production, and on the efficacy of four established biological control seed-head-feeding insects, which included three species of weevils and one fly species. We tested sheep and cattle grazing at three yellow starthistle growth stages-rosette, bolting, and late bud - at a site where all four biocontrol agents were established. The timing of grazing had a greater impact on yellow starthistle growth and bud production than the type of grazing animal. In comparison to the control, grazing at the rosette and bolting stage resulted in shorter plants both years of the study, but increased the number of buds following grazing at the bolting stage and at the rosette stage in 2003. Negligible seed production across treatments, in 2003, precluded detection of treatment effects. However, in 2004, grazing at the rosette and bolting stages resulted in a greater number of seeds per plant compared to the control and the late bud stage, which were similar. Results indicated that the timing of grazing did not negatively impact biocontrol efficacy. Eustenopus villosus adult injury and total insect larval damage were similar to control plants following each grazing treatment both years, indicating potential compatibility between targeted grazing and biocontrol for integrated management of yellow starthistle.
\end{abstract}

\section{Resumen}

Starthistle amarillo (Centaurea solstitialis L.) es una maleza invasora de significativa importancia en los pastizales del oeste de los Estados Unidos. Se llevaron a cabo experimentos de campo en 2003 y 2004 para determinar el efecto del pastoreo sobre el crecimiento de Starthistle amarillo, producción de brotes, y sobre la eficacia del control biológico utilizando cuatro insectos consumidores de brotes reproductivos, incluyendo tres especies de gorgojos y una especie de mosca. Se utilizaron ovejas y ganado vacuno en pastoreo en tres etapas de crecimiento de Starthistle amarillo_roseta, apertura y último brote—en un área donde los cuatro agentes de biocontrol fueron establecidos. La estación de pastoreo tuvo un efecto mayor sobre el crecimiento y la producción de brotes del Starthistle amarillo que el tipo de animal. En comparación con el control, el pastoreo en las etapas de roseta y apertura resultó en plantas más pequeñas en los dos años de estudio, pero se incrementó el número de brotes después del pastoreo en los estados de roseta y apertura en 2003. La producción de semilla fue insignificante en todos los tratamientos en 2003, lo que impidió la detección del efecto de los tratamientos aplicados. Sin embargo, en 2004, el pastoreo en las etapas de roseta y apertura resultó en un mayor número semillas por planta comparado con el control y la etapa de último botón, mismos que fueron similares. En conclusión: el tiempo de pastoreo no afectó negativamente la eficacia del control biológico. Adultos y larvas de Eustenopus villosus presentaron un daño similar en el control de plantas después de cada tratamiento de pastoreo durante los dos años, demostrando la potencial compatibilidad entre el pastoreo intencional y el control biológico para el manejo integrado del Starthistle amarillo.

Key Words: biological control, Centaurea solstitialis, integrated weed management, targeted grazing

\section{INTRODUCTION}

In the western United States, yellow starthistle (Centaurea solstitialis L.) is a weed of Mediterranean origin that displaces native plants in perennial bunchgrass rangelands (Sheley and Larson 1994) and invades sites dominated by early-maturing, exotic, annual grasses (Borman et al. 1991; Roché and Thill 2001). Yellow starthistle is estimated to occupy about 4 million

Research was funded by a grant from the USDA-CSREES-Western Regional IPM program. Correspondence: John Wallace, Dept of Plant, Soil, and Entomological Sciences, University of Idaho, Moscow, ID 83844, USA. Email: jwallace@uidaho.edu

Manuscript received 14 April 2007; manuscript accepted 21 February 2008. hectares, predominantly in California, Idaho, Oregon, and Washington (Roché et al. 1997). It is a facultative winter annual with a long taproot that facilitates use of deep soil moisture throughout the growing season, and is preadapted to the climatic patterns of the semiarid regions of the intermountain west (DiTomaso et al. 2003). At high densities, yellow starthistle can extract soil moisture from the entire soil profile and compete with shallow- and deep-rooted annual and perennial plant species (DiTomaso et al. 2003; Enloe et al. 2004). This competitive ability often results in the formation of large monospecific stands, which can radically reduce forage production and grazing capacity, and decrease biodiversity (Callihan et al. 1989). 
Integrated management of yellow starthistle combines two or more compatible strategies including targeted grazing, mowing, reseeding, burning, herbicides, and biological control (DiTomaso et al. 2000). Biological control has suppressed yellow starthistle seed production in California (Pitcairn et al. 2001; Woods et al. 2002) and Idaho (Connett et al. 2001). Six species of yellow starthistle seed-feeding insects are established in the United States. Three species of weevils (Coleoptera: Curculionidae): yellow starthistle bud weevil (Bangasternus orientalis Capiomont), yellow starthistle hairy weevil (Eustenopus villosus Boheman), and yellow starthistle flower weevil (Larinus curtus Hochut), and two species of flies (Diptera: Tephritidae): yellow starthistle peacock fly (Chaetorellia australis Hering) and banded yellow starthistle gall fly (Urophora sirunaseva Hering) have been introduced. A third tephritid fly, false peacock fly $(C$. succinea Hering), was accidentally introduced and has become widely established (Balciunas and Villegas 1999). Each biocontrol insect's life cycle is synchronized to a specific yellow starthistle phenological stage, providing sustained attack of susceptible seed heads throughout the growing season.

Targeted grazing is the application of livestock grazing at a specified season, intensity, and frequency to achieve specific vegetation management goals such as weed control (Frost and Launchbaugh 2004). Thomsen et al. (1993) determined that targeted grazing can effectively suppress yellow starthistle in California grasslands when grazing is timed to the bolting or late bud stage, and two or more grazing periods are applied during the growing season. Carefully managed livestock grazing has been shown to be effective in suppressing rangeland weeds (Launchbaugh and Walker 2006), such as yellow starthistle (Thomsen et al. 1989), spotted knapweed (Sheley et al. 2004), leafy spurge (Landgraf et al. 1984), dyers woad (West and Farah 1989), and rush skeletonweed (Groves and Cullen 1981). Few studies report combined targeted grazing and biological control. Grazing might enhance the effectiveness of biocontrol by reducing root biomass, by reducing seed output, or by opening up the plant canopy, which may create a condition that makes weeds more susceptible to damage from biocontrol agents (Jacobs et al. 2006; Launchbaugh and Walker 2006). Hansen (1993) and Jacobs et al. (2006) suggested that the combination of sheep grazing and introduced flea beetles might have a greater effect on leafy spurge abundance than either alone.

The response of yellow starthistle to the combination of targeted grazing and biological control has not been evaluated. Grazing by livestock may affect the quantity and quality of seed heads available to biological control insects. Understanding how targeted grazing and biocontrol can be applied together may provide a powerful and sustainable tool for integrated management of yellow starthistle.

The first objective of this study was to determine the effects of targeted livestock grazing on the growth and reproduction of yellow starthistle. The second objective was to determine if targeted grazing affects the efficacy of yellow starthistle biological control insects. We hypothesized that the combination of biological control and targeted grazing with sheep or cattle would cause a greater reduction in yellow starthistle flower heads than biological control alone.

\section{METHODS}

\section{Study Site}

A field study was conducted in 2003 and 2004 at a yellow starthistle-dominated rangeland site $19 \mathrm{~km}$ southeast of Genesee, Idaho (lat $46^{\circ} 28^{\prime} \mathrm{N}$, long $116^{\circ} 51^{\prime} \mathrm{W}$ ). The plant community included cheatgrass (Bromus tectorum L.), bulbous bluegrass (Poa bulbosa L.), ventenata (Ventenata dubia L.), and medusahead rye (Taeniatherum caput-medusae L.). Perennial grasses established at the site included Idaho fescue (Festuca idaboensis E.), Kentucky bluegrass (Poa pratensis L.), Sandberg's bluegrass ( $P$. sandbergii L.), and smooth brome (Bromus inermis L.). Forb species at the site included hairy vetch (Vicia villosa R.), St. Johnswort (Hypericum perforatum L.), storksbill (Erodium cicutarium [L.] L'Her. ex Ait.), goatsbeard (Tragopogon spp.), and fiddleneck (Amsinckia spp.). Soils are of loess origin and are moderately deep with hard subsoils under dry conditions.

Four of the six introduced biological control insect species were well established at the field site, including the three weevils, B. orientalis, E. villosus, and L. curtus, and one fly, C. succinea. Preliminary surveys indicated that the density of each insect species at the site was similar to their density at surrounding sites in the area (L. Wilson, unpublished data, 2004).

\section{Experimental Design and Grazing Treatments}

To evaluate how livestock grazing affects yellow starthistle, we applied grazing by cattle or sheep (use of livestock approved by University of Idaho Animal Care and Use Committee [Protocol 2002-48]) at three yellow starthistle growth stages: rosette, bolting, and late bud. The experimental design was a randomized complete block $2 \times 3+1$ factorial treatment structure consisting of two grazing treatments (sheep and cattle), three growth stages (rosette, bolting, and late bud) and an ungrazed control treatment. Treatments were replicated four times for a total of 28 plots/paddocks. Because of area constraints, one replication of the late bud cattle grazing treatment was not included; thus a total of 27 paddocks were included in the study.

Grazing treatments were applied in fenced $22 \times 22 \mathrm{~m}$ paddocks. Each grazing treatment was applied to the same randomly selected paddock once during the 2003 growing season and again in 2004. The stocking rate ranged from 41 to 310 animal unit days per hectare depending on forage supply at the time of grazing. Grazing was initiated when visual estimates confirmed that $80 \%$ of yellow starthistle plants targeted for specific treatments had reached the appropriate growth stage. Grazing treatments at the rosette growth stage took place in early May (2-10 May), treatments targeting the bolting stage occurred in early June (2-15 June), and grazing during the late bud stage took place in early July (25 June-4 July). The duration of grazing varied according to the amount of biomass in each paddock and the rate of utilization by the livestock. Duration of grazing ranged from 2 to 3.5 days per paddock. Livestock were removed from the paddock when $75 \%-85 \%$ of yellow starthistle biomass was removed.

To measure the effect of grazing on individual yellow starthistle plants, five quadrats $\left(0.375 \mathrm{~m}^{2}\right)$ were placed and 
permanently marked in each paddock, 1-2 days after each grazing treatment. Quadrats were established where at least five grazed plants occurred within the plot area. Five grazed plants were randomly selected within each quadrat and tagged, resulting in 25 tagged, yellow starthistle plants in each paddock or 100 tagged plants per treatment.

The experiment was terminated on 20 August 2003 and 3 August 2004, when plant growth had ceased, and before seeds disseminated from flower heads. All tagged plants were clipped at the soil surface and taken to the laboratory for dissection. Plant height, the number of secondary branches, and the total number of buds were recorded for each tagged plant. Each bud was categorized as an immature bud or flower head. All stages of bud development prior to flowering were defined as immature buds; those at or past the bloom stage were defined as flower heads.

Immature buds and flower heads were inspected for external E. villosus adult feeding or oviposition scars. Adults emerge from overwintering in synchrony with early bud formation of yellow starthistle, and both sexes extensively chew holes to feed on young buds (Wilson et al. 2003). Additionally, females chew holes at the base of a bract in mature buds to lay eggs. Damage to buds from adults can be extensive and can even be fatal to small buds. Scarring due to adult feeding or oviposition was grouped together for purposes of analyses and referred to as $E$. villosus adult injury.

Flower heads were dissected and inspected for biocontrol insect larval damage, which results from larval feeding and pupation within the flower heads. Pupae and adults within flower heads were identified to species, and larvae were distinguished between flies and weevils. Weevil larvae were identified to species based on position within the flower head when such characteristics were distinguishable. Unidentified larvae were recorded and grouped with flower heads containing a pupae chamber, larvae frass, or chewed seeds in buds that did not contain a biocontrol insect.

The number of seeds per flower head was recorded. Seeds were identified as damaged or undamaged from larval feeding. Only intact, undamaged seeds were considered in the analysis.

\section{Statistical Analysis}

Data from plant-level response variables (height, secondary branching, total buds, and seed) were tested for assumptions of normality with the use of the NORMAL option in PROC UNIVARIATE (SAS Institute, 2004). Bud and seed production data were natural $\log$ transformed $(\ln [y+0.5])$ to achieve normality. Biocontrol insect data collected from bud and flower-head dissections were used to calculate the proportion of total buds per plant that reached flower-head stage; the proportion of immature buds and flower heads per plant with E. villosus adult injury; and the proportion of flower heads per plant with larval damage. Proportion data was arcsine squareroot transformed to achieve normality.

Analysis of variance, by year, was used to test the effect of grazing animal and grazing stage on each response variable listed above. The model included grazing animal, grazing stage, block, and their interactions. Fisher's protected least-significant difference $(\alpha=0.05)$ was used to separate main-effect means.
Table 1. Mean $( \pm S E)$ height, number of secondary branches, and total number of buds per plant following targeted grazing of yellow starthistle by cattle and sheep at three growth stages (rosette, bolting, late bud) in 2003 and 2004. Pairwise comparisons between main-effect means are separated with the use of Fisher's least significant difference. Main effect means with same letter in the same column, within each year, are not significantly different $(P>0.05)$. Main-effect means followed by asterisks are not significantly different $(P>0.05)$ than theô control.

\begin{tabular}{|c|c|c|c|}
\hline Main effects & Height & Secondary branching & Total buds ${ }^{1}$ \\
\hline & -------- & ------ 2003--- & --1--1 \\
\hline \multicolumn{4}{|l|}{ Grazing animal } \\
\hline Cow & $24 \pm 0.5 a$ & $1.5 \pm 0.1 \mathrm{a}$ & $3.3 \pm 0.6 a$ ** \\
\hline Sheep & $21 \pm 0.3 b$ & $1.5 \pm 0.1 \mathrm{a}$ & $3.2 \pm 0.6 a * *$ \\
\hline \multicolumn{4}{|l|}{ Grazing stage } \\
\hline Rosette & $25 \pm 0.5 x$ & $1.6 \pm 0.1 x$ & $4.8 \pm 0.5 x$ \\
\hline Bolting & $17 \pm 0.5 y$ & $2.0 \pm 0.1 x$ & $4.3 \pm 0.6 x$ \\
\hline Late bud & $26 \pm 0.5 x$ & $0.8 \pm 0.1 y^{* *}$ & $1.6 \pm 0.6 y^{* *}$ \\
\hline Control & $34 \pm 1.3$ ** & $0.8 \pm 0.2$ ** & $2.5 \pm 0.6$ ** \\
\hline \multicolumn{4}{|l|}{ Grazing animal } \\
\hline Cow & $40 \pm 0.7 \mathrm{a}$ & $4.4 \pm 0.1 \mathrm{a}$ & $13.1 \pm 0.6 a^{* *}$ \\
\hline Sheep & $36 \pm 0.7 \mathrm{a}$ & $4.0 \pm 0.1 \mathrm{a}$ & $13.6 \pm 0.6 a^{* *}$ \\
\hline \multicolumn{4}{|l|}{ Grazing stage } \\
\hline Rosette & $40 \pm 0.8 x$ & $4.3 \pm 0.2 x$ & $8.4 \pm 0.6 y$ ** \\
\hline Bolting & $33 \pm 0.9 y$ & $4.5 \pm 0.1 x^{* *}$ & $21.1 \pm 0.6 x$ \\
\hline Late bud & $41 \pm 1.0 x$ & $3.7 \pm 0.2 x$ & $11.0 \pm 0.6 y$ ** \\
\hline Control & $49 \pm 1.8^{* *}$ & $5.3 \pm 0.4$ ** & $12.9 \pm 0.7^{* *}$ \\
\hline
\end{tabular}

${ }^{1}$ Statistical inferences based on natural log transformation.

Orthogonal contrasts were used to test within treatment effects if a significant grazing animal by grazing stage interaction occurred.

\section{RESULTS}

\section{Effect of Grazing on Yellow Starthistle Growth and Bud Production}

Grazing animal by grazing stage interactions were not detected $(P>0.05)$ in the analyses of plant response variables including height, secondary branching, and total bud production. Results indicate that the type of grazing animal had minimal impact on yellow starthistle plant growth and bud production. Plants grazed by sheep were significantly shorter $(P=0.0163)$ in comparison to cattle treatments in 2003 , but did not differ in 2004 (Table 1). Grazing with sheep or cattle resulted in shorter $(P<0.05)$ plants than the ungrazed control. Grazing animal effects were not detected $(P>0.05)$ in analysis of secondary branching or total bud (immature buds + flower heads) production in both years of the study. At each growth stage, grazing with sheep resulted in a smaller $(P=0.0067)$ proportion of flower heads per plant in 2004.

The timing of grazing had a significant effect on plant height in $2003(P=0.0008)$ and $2004(P=0.0075)$. Grazing at the bolting stage resulted in shorter plants in comparison to rosette and late bud treatments, and all grazing treatments resulted in shorter plants than the ungrazed control during both years of the study (Table 1). The timing of grazing affected 


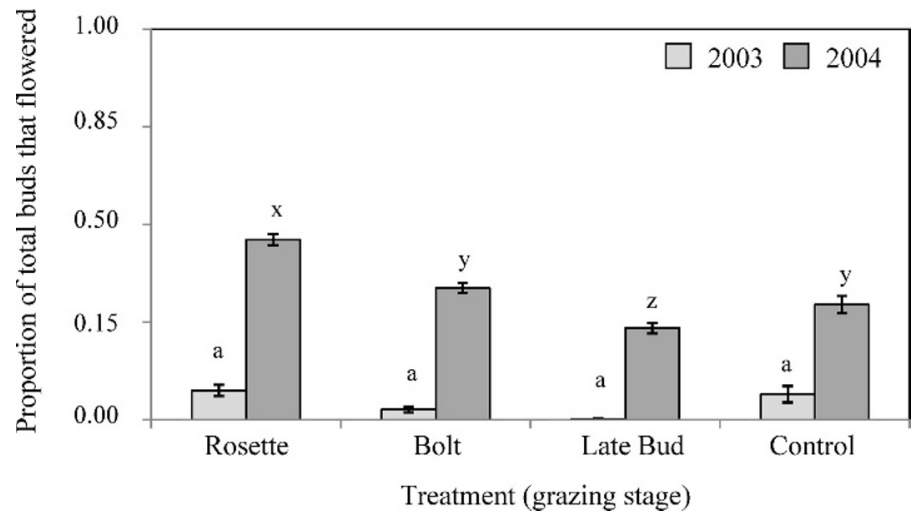

Figure 1. Mean ( $\pm \mathrm{SE}$ ) proportion of total buds (per plant) that reached flower-head stage following grazing at three yellow starthistle growth stages in 2003 and 2004. Backtransformed means are presented on an arcsine-square root scale. Statistical inferences are based on arcsinesquare root transformation. Means are separated with the use of Fisher's least significant difference pairwise comparisons. Means with same letter are not significantly different $(P>0.05)$.

$(P=0.0006)$ the number of secondary branches in 2003 (Table 1). Grazing at the rosette and bolting stages resulted in more secondary branching compared to the late bud stage and the control. Conversely, in 2004, ungrazed plants produced more secondary branches in comparison to rosette or late bud treatments. The bolting stage was statistically similar to each grazing treatment.

The timing of grazing had a significant effect on total bud production in $2003(P=0.0023)$ and $2004(P=0.0012)$. Plants grazed at the rosette and bolting stages resulted in a greater number of buds in comparison to the late bud and control treatments in 2003 (Table 1). The ungrazed control was statistically similar to the late bud stage. In 2004, plants grazed at the bolting stage resulted in greater bud production in comparison to each treatment, including the control, which was statistically similar to the rosette and late bud treatments.

Yellow starthistle growth and bud production differed between years. Ungrazed plants were shorter and produced fewer secondary branches and buds in 2003 compared to 2004 (Table 1). In 2003, mean seed production was negligible $(<1$ seed/plant) across treatments. Conversely, mean seed production ranged from 8 to 72 seeds/plant in 2004. Differences in the magnitude of yellow starthistle response to grazing between years may be attributed, in part, to precipitation patterns in 2003 and 2004. In 2003, precipitation occurred predominately in March and April, and decreased dramatically after the third week in April, which produced midsummer drought conditions. In 2004, precipitation was greater in April and May and continued into the first week of June.

The effect of grazing on the proportion of buds per plant that reached the flower-head stage at the conclusion of the study was different across years (Fig. 1). Within the ungrazed control, the mean percentage of buds per plant that flowered was $1 \%$ in 2003 and $20 \%$ in 2004 . No treatment effects were detected in $2003(P=0.2205)$. In 2004 , the timing of grazing had a significant effect $(P<0.0001)$ on the proportion of buds that flowered. Grazing at the rosette stage resulted in a greater proportion of flower heads per plant than other treatments and

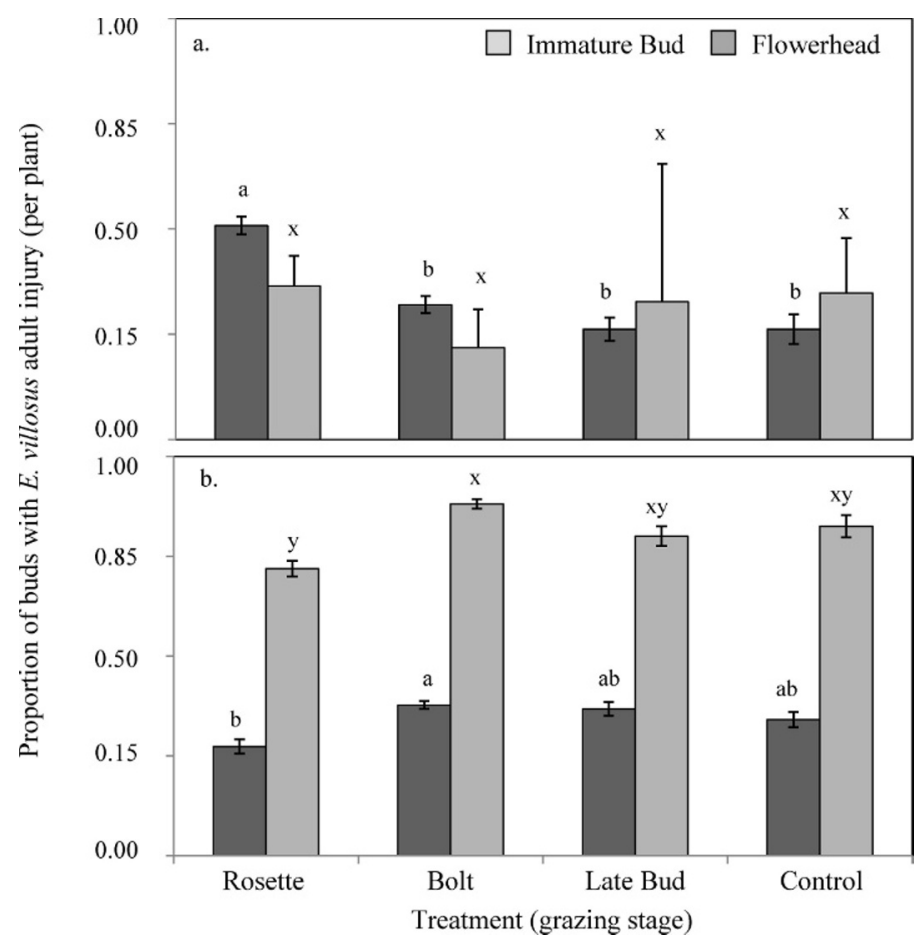

Figure 2. Mean ( $\pm \mathrm{SE}$ ) proportion of immature buds and flower heads (per plant) with $E$. villosus adult injury following grazing at three yellow starthistle growth stages in a, 2003 and b, 2004. Backtransformed means are presented on an arcsine-square root scale. Statistical inferences are based on arcsine-square root transformation. Means are separated with the use of Fisher's least significant difference pairwise comparisons. Means with the same letter (within year) are not significantly different $(P>0.05)$.

the ungrazed control. Grazing at the late bud stage resulted in smaller proportion of flower heads per plant in comparison to the bolting stage and the ungrazed control, which did not differ.

\section{Effect of Grazing on Biocontrol Insect Efficacy}

In analyses of biocontrol insect data, neither grazing animal nor grazing animal by grazing stage interactions were detected $(P>0.05)$. The timing of grazing to different yellow starthistle growth stages influenced the rate of biocontrol insect activity.

E. villosus adult injury occurred on $17 \%$ of immature buds and $28 \%$ of flower heads in the ungrazed control treatment in 2003 (Fig. 2a). The timing of grazing significantly impacted $(P=0.0071)$ E. villosus adult injury on immature buds. The rate of E. villosus adult injury was greater on plants grazed at the rosette stage compared to other grazing treatments and the ungrazed control (Fig. 2a). The ungrazed control did not differ from the bolting and late bud treatments. Few plants $(n=158)$ produced flower heads, and treatment effects were not detected in 2003. E. villosus adult injury occurred on $27 \%$ of immature buds and $93 \%$ of flower heads in the ungrazed control treatment in 2004 (Fig. 2b). Significant grazing stage effects occurred in comparisons of immature buds $(P=0.0598)$ and flower heads $(P=0.0219)$. The rate of E. villosus adult injury on both immature buds and flower heads of plants grazed at the bolting stage was greater in comparison to the rosette stage, 
Table 2. Presence of four biocontrol insects in yellow starthistle flower heads expressed as a percent of total larval damage in flower heads, by treatment (grazing stage) and year.

\begin{tabular}{|c|c|c|c|c|c|c|}
\hline \multirow[b]{2}{*}{ Treatment } & \multirow[b]{2}{*}{ Year } & \multicolumn{5}{|c|}{ Percent of total larval damage } \\
\hline & & Bangasternus orientalis & Chaetorellia succinea & Eustenopus villosus & Larinus curtus & Unknown $^{1}$ \\
\hline \multirow[t]{2}{*}{ Rosette } & 2003 & 9 & 0 & 30 & 3 & 58 \\
\hline & 2004 & 2 & 3 & 60 & 5 & 30 \\
\hline \multirow[t]{2}{*}{ Bolting } & 2003 & 21 & 7 & 26 & 2 & 43 \\
\hline & 2004 & 1 & 14 & 52 & 3 & 30 \\
\hline \multirow[t]{2}{*}{ Late bud } & 2003 & 19 & 4 & 19 & 0 & 58 \\
\hline & 2004 & 3 & 19 & 59 & 9 & 11 \\
\hline \multirow[t]{2}{*}{ Control } & 2003 & 14 & 0 & 14 & 0 & 71 \\
\hline & 2004 & 0 & 5 & 59 & 4 & 33 \\
\hline
\end{tabular}

${ }^{1}$ Presence of unidentified insect larvae, pupal chamber, larval frass, or larval-feeding-damaged seeds.

but did not differ from the late bud stage and the ungrazed control (Fig. 2b).

The presence of individual insect species was insufficient to test treatment effects of larval feeding during both years of the study. Unknown larval damage represented $43 \%-71 \%$ of observed larval damage in 2003, and $11 \%-33 \%$ in 2004 across treatments (Table 2). E. villosus was observed at greater rates than other biocontrol insects, representing $14 \%-30 \%$ of all larval damage in 2003 and $52 \%-60 \%$ in 2004 (Table 2). B. orientalis accounted for $9 \%-21 \%$ of larval damage in 2003 , but declined in 2004. C. succinea accounted for minimal larval damage in 2003, but represented $3 \%-19 \%$ in 2004. A negligible number of L. curtus was collected each year of the study.

Larvae of biocontrol insects were pooled across species to determine the proportion of flower heads per plant with larval damage. Grazing did not affect the rates of larval damage in 2003 ( $P=0.7753$; Fig. 3$)$, but did affect $(P=0.0054)$ larval damage in 2004 (Fig. 3). The proportion of flower heads with larval damage was greater in plants grazed at the bolting and

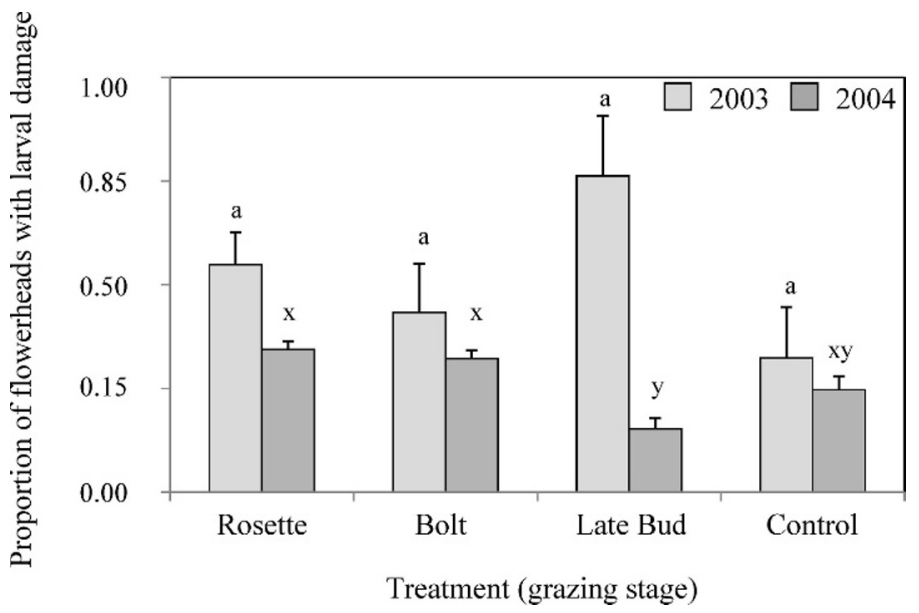

Figure 3. Mean $( \pm S E)$ proportion of flower heads (per plant) with larval damage following grazing at three yellow starthistle growth stages in 2003 and 2004. Backtransformed means are presented on an arcsinesquare root scale. Statistical inferences are based on arcsine-square root transformation. Means are separated with the use of Fisher's least significant difference pairwise comparisons. Means with the same letter are not significantly different $(P>0.05)$. rosette stages in comparison to the late bud stage, but did not differ from the ungrazed control in 2004. The control was statistically similar to all treatments.

Treatment effects $(P=0.9225)$ were not detected in the number of seeds per plant in 2003 (Fig. 4). Seed production was negligible across treatments including the ungrazed control. In 2004, grazing at the rosette and bolting stages resulted in more $(P=0.0006)$ seeds per plant than the late bud stage and the control (Fig. 4).

\section{DISCUSSION}

The results of our study indicate that yellow starthistle growth and bud production is significantly influenced by the timing of grazing, but is minimally influenced by the type of grazing animal. Thomsen et al. (1993) also found that animal species was less important than timing of grazing for the suppression of yellow starthistle.

Grazing at the bolting stage resulted in shorter yellow starthistle plants, but produced more buds per plant compared to the ungrazed control during both years of the study. Grazing at the rosette stage also resulted in shorter plants throughout

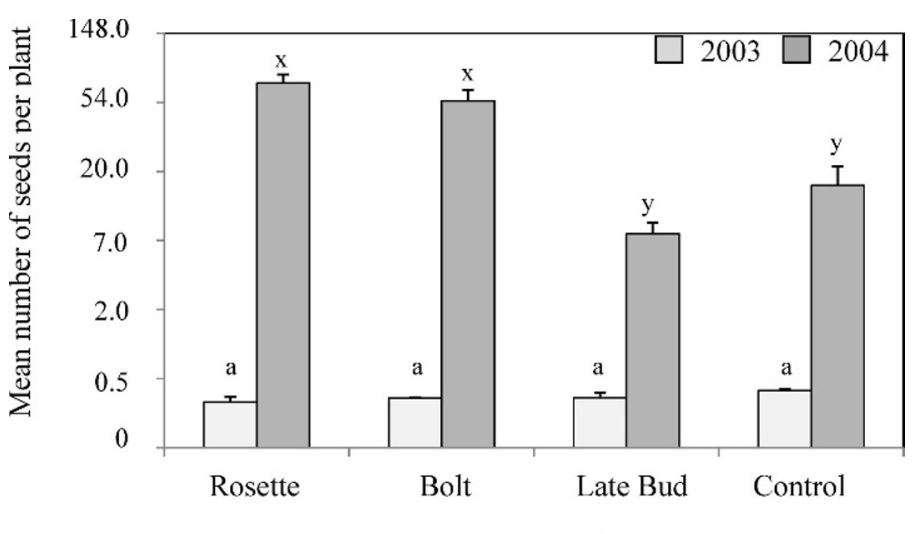

Treatment (grazing stage)

Figure 4. Mean $( \pm S E)$ number of seeds per plant following grazing at three yellow starthistle growth stages in 2003 and 2004. Backtransformed means are presented on a natural-log scale. Statistical inferences are based on natural-log transformation. Means are separated with the use of Fisher's least significant difference pairwise comparisons. Means with same letter are not significantly different $(P>0.05)$. 
the study, and produced a greater number of buds in comparison to the control in 2003. Such a mechanism, in which grazing results in overcompensation toward reproductive structures, has been documented for grasses (McNaughton et al. 1983) and herbaceous plants (Paige and Whitham 1987).

The ability of plants to regrow following grazing is dependent upon which phenological stage is grazed, plant competition, and the prevailing nutrient and water regimes (Maschinski and Whitham 1989). Differences that occurred in the magnitude of seed yields between years suggest that the net effect of grazing on seed yields is strongly mediated by seasonal water regimes. Although grazing at the rosette and bolting stages yielded more buds compared to ungrazed plants, seed production was negligible and did not differ from ungrazed plants or other grazing treatments in 2003, which suggests that prevailing drought conditions negated the benefits of increased bud production. Conversely, grazing at the bolting stage, as well as the rosette stage, resulted in a net increase in seed production per plant compared to ungrazed plants in 2004 under more favorable precipitation patterns. Such trends suggest that grazing yellow starthistle early in the growing season may result in increased seed production when spring soil moisture prevails.

Recent studies have demonstrated the importance of wateruse patterns for the competitiveness of yellow starthistle. Enloe et al. (2004) determined that yellow starthistle communities deplete water longer into the growing season and at greater soil depths in comparison to annual and perennial grass communities. Consequently, integrated management of yellow starthistle should apply targeted grazing to late bud stages to limit the opportunity for increased bud production. Though the effect of grazing animal was negligible, we observed during the study that sheep selectively graze yellow starthistle later into the growing season than cattle. In a more recent study, goats appear to graze yellow starthistle readily later in the growing season (K. Launchbaugh, unpublished data, 2007). Thus, targeted grazing of yellow starthistle may be most effective when sheep or goats are applied to plants at the late bud stage.

Our results suggest that timing of grazing to different yellow starthistle growth stages did not negatively affect the efficacy of biocontrol insects. E. villosus adult feeding or oviposition occurred on immature buds and flower heads across grazing treatments at a rate that was equal to or greater than the ungrazed control. Insect larval damage in flower heads of grazed plants also occurred at rates equal to the ungrazed control. Our results also suggest that $E$. villosus, which is the most effective biocontrol agent in northern Idaho (L. Wilson, unpublished data, 2004) and California (Pitcairn et al. 2001), may be uniquely adapted for integrated yellow starthistle management using targeted grazing. Greater bud production, in response to grazing at early growth stages, may optimize E. villosus impact by increasing the abundance of feeding and oviposition sites.

In conclusion, we suggest that suppression of invasive plants using a combination of livestock and insect herbivores may increase when 1) the regrowth of plants following grazing is limited or predictable, 2) grazing elicits allocation of resources to favor biocontrol insects, 3) grazing and biocontrol activity are partitioned in space or time, and 4) direct negative interactions between livestock and biocontrol insects are minimized.

\section{MANAGEMENT IMPLICATIONS}

Targeted grazing and biological control are compatible strategies for the management of yellow starthistle. Grazing timed to different yellow starthistle growth stages does not negatively impact biocontrol insect efficacy. Rates of larval damage and E. villosus adult injury were similar following each grazing treatment in comparison to ungrazed plants. The timing of grazing had a greater impact on yellow starthistle growth and bud production than the type of grazing animal. Grazing timed to early growth stages, rosette and bolting, can result in increased seed yields under favorable climatic conditions, and thus should be avoided. Grazing at the late bud stage limits bud development and likely soil moisture availability by decreasing the length of the growing season following grazing, which may result in decreased seed yields.

\section{ACKNOWLEDGMENTS}

We thank Georjana Pokorney, Todd Pankratz, Elaine Hovde, Lovina Roselle, Gen Hanson, Katie Johnson, and Kara Anlauf, for technical assistance during the field experiments and laboratory analyses. Dr. Bill Price provided statistical guidance throughout the experiment. We also thank Jon Nilsson, Dennis Moss and Jeff Barnett for the use of land and livestock for the experiments.

\section{LITERATURE CITED}

Balciunas, J., and B. Villegas. 1999. Two new seed head flies attack yellow starthistle. California Agriculture 53:8-11.

Borman, M. M., W. C. Krueger, and D. E. Johnson. 1991. Effects of established perennial grasses on yields of associated annual weeds. Journal of Range Management 44:318-322.

Callihan, R. H., T. S. Prather, and F. E. Northam. 1989. Invasion by yellow starthistle (Centaurea solstitialis). In: P. K. Fay and J. R. Lacey [EDs.]. Proceedings of the Knapweed Symposium; 4-5 April 1989; Bozeman, MT, USA. p. 73-76.

Connett, J. F., L. M. Wilson, J. P. McCaffrey, and B. L. Harmon. 2001. Phenological synchrony of Eustenopus villosus (Coleoptera: Curculionidae) with Centaurea solstitialis in Idaho. Environmental Entomology 30:439-442.

Ditomaso, J. M., G. B. Kyser, S. B. Orloff, and S. F. Enloe. 2000. Integrated strategies offer site-specific control of yellow starthistle. California Agriculture 54:30-36.

Ditomaso, J. M., G. B. Kyser, and C. B. Pirosko. 2003. Effect of light and density on yellow starthistle (Centaurea solstitialis) root growth and soil moisture use. Weed Science 51:334-341.

Enloe, S. F., J. M. Ditomaso, S. B. Orloff, and D. J. Drake. 2004. Soil water dynamics differ among rangeland plant communities dominated by yellow starthistle (Centaurea solstitialis), annual grasses, or perennial grasses. Weed Science 52:929-935.

Frost, R. A., and K. L. Launchbaugh. 2004. Prescription grazing for rangeland weed management. Rangelands 25:43-47.

Groves, R. H., And J. M. Cullen. 1981. Chrondrilla juncea in Australia. Distribution and control. Orange, Australia: New South Wales Department of Agriculture, Bulletin No. 68.

Hansen, R. 1993. Effects of Aphthona flea beetles and sheep grazing in leafy spurge. In: Proceedings of the 1993 Great Plains Agricultural Council Leafy Spurge Task Force Symposium; July 26-28; Silver Creek, CO, USA. p. 47-48.

Jacobs, J. S., R. L. Sheley, AND J. J. BoRKowski. 2006. Integrated management of leafy spurge-infested rangeland. Rangeland Ecology and Management $59: 475-82$. 
Landgraf, B. K., P. L. Fay, and K. M. Havstad. 1984. Utilization of leafy spurge (Euphorbia esula) by sheep. Weed Science 32:348.

LAunCHBAUGh, K. L., AND J. W. WaLKER. 2006. Targeted grazing—a new paradigm for livestock management. In: K. Launchbaugh, J. W. Walker, and R. J. Daines [EDs.] Targeted grazing: a natural approach to vegetation management and landscape enhancement. Centennial, CO, USA: American Sheep Industry Association. p. 2-8.

Maschinski, J., And T. G. Whitham. 1989. The continuum of plant responses to herbivory: the influence of plant association, nutrient availability, and timing. The American Naturalist 134:1-19.

McNaughton, S. J., L. L. Wallace, and M. B. Coughenour. 1983. Plant adaptation in an ecosystem context: effects of defoliation, nitrogen, and water on growth on an African C4 sedge. Ecology 64:307-318.

Paige, K. N., And T. G. Whitham. 1987. Overcompensation in response to mammalian herbivory: the advantage of being eaten. American Naturalist 129:407-416.

Pitcairn, M. J., D. M. Woods, D. B. Joley, and V. Popescu. 2001. Six year population buildup and combined impact of biological control insects on yellow starthistle. In: D. M. Woods [ED.]. Biological control program annual summary. Sacramento, CA, USA: Department of Food and Agriculture, Plant Health and Pest Prevention Services. p. 66-67.

Roché, C. T., AND D. C. Thill. 2001. Biology of common crupina and yellow starthistle, two Mediterranean winter annual invaders in western North America. Weed Science 49:439-447.

Roché, C. T., D. C. Thill, and B. Shafl. 1997. Reproductive phenology in yellow starthistle (Centaurea solstitialis). Weed Science 45:763-770.
SAS Institute Inc. 2004. SAS Online Doc ${ }^{\circledR}$ 9.1.2. Cary, NC, USA: SAS Institute. p. 5136-5137.

Sheley, R. L., J. S. Jacobs, and J. M. Martin. 2004. Integrating 2,4-D and sheep grazing to rehabilitate spotted knapweed-infested rangeland. Journal of Range Management 57:371-374.

Sheley, R. L., and L. L. Larson. 1994. Comparative growth and interference between cheatgrass and yellow starthistle seedlings. Journal of Range Management 47:470-474.

Thomsen, C. D., W. A. Williams, M. R. George, W. B. Henry, F. L. Ball, and R. S. KNIGHt. 1989. Managing yellow starthistle on rangelands. California Agriculture 43:4-7.

Thomsen, C. D., W. A. Williams, M. R. Vayssieres, F. L. Bell, and M. R. George. 1993. Controlled grazing on annual grassland decreases yellow starthistle. California Agriculture 47:36-40.

West, N. E., and K. O. Farah. 1989. Effects of clipping and sheep grazing on dyers woad. Journal of Range Management 42:5-10.

Wilson, L. M., C. Jette, J. Connett, And J. P. McCaffrey. 2003. Biology and biological control of yellow starthistle. 2nd ed. Morgantown, WV, USA: US Forest Service, USDA, Report No. FHTET-1998-17. p. 11-47.

Woods, D. M., M. J. Pitcairn, D. B. Joley, and V. Popescu V. 2002. Seasonal impact of yellow starthistle biological control insects. In: D. M. Woods [ED.]. Biological control program annual summary, 2001. Sacramento, CA, USA: California Department of Food and Agriculture, Plant Health and Pest Prevention Services. p. 60-62. 